\title{
Towards integrated interdisciplinary research of archaeological objects in museums and their sustainable conservation
}

\section{INA REICHE}

IRCP-C2RMF UMR 8247 CNRS

Presenting Author: ina.reiche@chimieparistech.psl.eu

The talk aims at discussing the state of the art and the challenges of research on objects from archaeological museum collections by presenting different practical case studies. I report on the study of ancient Egyptian pigments [1], glasses from Amarna [2] and of Mesopotamian glazed ceramics such as those of the Ishtar gate from Babylon [3]. This interdisciplinary research includes methods from the field of geochemistry, analytical chemistry, high energy physics, material sciences and approaches from the humanities.

The presented studies basically concern objects kept in German and French museum collections and are considered from divers perspectives in order to discuss current and future global challenges that innovative museums and their science departments have to face. Issues that are especially discussed are how:

- addressing well-adapted research questions,

- establishing an aim-oriented analytical strategy to study museum items effectively in their context

- producing meaningful data sets understandable by other research communities,

- dealing with complex data sets created by complementary methods,

- contributing to sustainable conservation measures,

- storing the data according to the FAIR guidelines,

- presenting and communicating successful studies to other communities and the broad public,

- training young researchers in interdisciplinary research and

- performing collaborative research within national and European research infrastructures such as IPERION-CH, IPERION-HS and E-RIHS.

References:

[1] Pagès-Camagna, Reiche, Brouder, Cabaret, Rossano, Kanngießer, Erko (2006), X-Ray Spectrometry 35, 141-145.

[2] Hodgkinson, Röhrs, Müller, Reiche (2019), STAR: Sci. \& Technol. Archaeol. Res. 5(2), 36-52.

[3] Reiche, I. et al. (2018), Das Ischtar-Tor und die Prozessionsstraße archäometrisch betrachtet. Neue Einblicke in die verwendeten Glasurfarben und den Erhaltungszustand der glasierten Ziegel im Pergamon-Museum, Berlin. in: Archäometrie und Denkmalpflege 2018, Verlag Deutsches Elektronen-Synchrotron DESY, 144-147. 